\title{
INTERACTIVE EFFECT OF ARBUSCULAR MYCORRHIZAL FUNGI INOCULATION AND PHOSPHORUS FERTILIZER APPLICATOIN ON YIELD AND NUTRIENT CONTENT OF RED PEPPER (Capsicum annuum L.) IN A SEMI-ARID REGION
}

\author{
AlmaCA, A. ${ }^{1 *}-$ AlmaCA, N. D. ${ }^{2}-$ SenBAYRAM, M. ${ }^{1}$ \\ ${ }^{1}$ Department of Soil Science and Plant Nutrition, Faculty of Agriculture, Harran University, \\ Sanliurfa, Turkey \\ ${ }^{2}$ GAP Agricultural Research Institute, Sanliurfa, Turkey \\ ${ }^{*}$ Corresponding author \\ e-mail: almaca@harran.edu.tr; phone:+90-414-318-3675 \\ (Received $18^{\text {th }}$ Jan 2021; accepted $14^{\text {th }}$ May 2021)
}

\begin{abstract}
High soil pH coupled with low available soil phosphorus (P) and poor utilization efficiency of added $\mathrm{P}$ is a significant constraint limiting the productivity of irrigated crops in semi-arid regions. The aim of this three-years field study was to investigate the interactive effect of mycorrhiza (Glomus mosseae) inoculation and phosphorus application on the growth, nutrient uptake and yield components of red pepper (Capsicum annиum L.). The experiment was consisted of four treatments: i) control, ii) mineral-P fertilizer application, iii) mycorrhiza inoculation, and iv) mineral $\mathrm{P}+$ mycorrhizal inoculation. The lowest mean fresh fruit yield was measured in 2013, and the highest mean yield was obtained in 2014. Overall, the results indicated that mycorrhizal inoculation and mycorrhiza + phosphorus applications increased yield by up to $25 \%$ compared to the control treatment specifically in productive years. The number of spores in soil and pepper yield had a significant positive correlation. Moreover, mycorrhiza inoculation clearly increased plant $\mathrm{Zn}$ contents (only significant in 2014). Overall, the study suggest that inoculation of mycorrhiza may increase nutrient $(\mathrm{P}$ and $\mathrm{Zn})$ uptake and fruit yield in $\mathrm{P}$ supplied pepper planted soils, however, the environmental factors seems to play an important role in controlling their interaction.
\end{abstract}

Keywords: soil, sustainability, fruit quality, zinc, colonization

\section{Introduction}

Ongoing global warming and rapidly growing world population threaten the food security and sustainable life on earth. The only way to cope with the effect of increased population pressure on the soils is to increase the fertility of currently available agricultural lands. Furthermore, sustainable soil and plant management practices needs to be developed to minimize erosion, soil salinity, soil and water pollutions without altering the crop yield.

Previous studies indicated that plant nutrients are taken by plant roots as well as fungi species, often called mycorrhiza, diagnosed under a microscope and producing large amounts of hyphae (Leifheit et al., 2014; Harikumar et al., 2015; Liu et al., 2016). Arbuscular mycorrhizal fungi (AMF) can form associations with the roots of most of the terrestrial plant species, and exchange soil-derived nutrients for plant-derived photosynthates and lipids (Coccina et al., 2019). Mycorrhiza is infecting to plant communities through spores that exist in the soil or added via various treatments such as with mineral or organic fertilizers. The majority of plant roots are dependent on the mycorrhiza system (Smith and Read, 2008; Ortas, 2019a), however, mycorrhiza spore availability for large agricultural areas may not be sufficient in high productive systems (Simpson and Daft, 1990; Klironomos, 2003). The mycorrhiza spores used in the previous 
studies have mostly been produced by plant roots that are artificially or naturally inoculated with mycorrhizal inoculation (Al-Amri, 2019; Wang et al., 2020). Since mycorrhiza fungi are symbiotic to plant roots, they generally reproduce in the rhizosphere of host plants (Gilmore, 1968; Gerdemann and Trappe, 1974; Sylvia and Jarstfer, 1994).

In terrestrial ecosystem, mycorrhizal fungi play a key role in the acquisition of mineral nutrients, such as P, N, Fe, Zn, Cu and Mo (Aggangan et al., 1999; Smith and Read, 2008) and increases plant growth along with yield. Also according to Smith and Read (2008) mycorrhizal inoculation provides water and mineral nutrients (such as $\mathrm{P}$ and $\mathrm{N}$ ) to plants in exchange for carbohydrates produced photosynthetically. Mycorrhizal fungus increases the plant root surface area by producing a large number of hyphae, explore the soil more efficiently than plant roots and take nutrients far beyond the nutrient depletion zone around the roots (Wang et al., 2020). Most agricultural crops are responsive to mycorrhizal symbiosis, however, the degree to which plants respond to mycorrhizal colonization differs significantly among species (Ortas, 2012a, 2018). Pepper plant is highly mycorrhizal dependent under field conditions (Almaca et al., 2013).

Pepper is one of the most produced and consumed products among vegetables, and world vegetable production is approximately 732 Ktons (FAO, 2018). Pepper is highly consumed in Vietnam, India, USA followed by Middle East, Mediterranean Basin countries. Due to the high yielding physiology of pepper, its nitrogen and phosphorus requirement is higher compared with the other the field crops which necessitate proper nutrient management. For increasing nutrient uptake efficiency of pepper mycorrhiza inoculation in field conditions has been proposed by Al Raddad (1987) and Ortas (2012b). The results of Al Raddad (1987) indicated clearly that the abundance and composition of native mycorrhizal communities determined establishment success of the inoculant. Additionally, Al Raddad (1987) determined that inoculation of G. fasciculatum, G. monosporum and G. mosseae mycorrhiza varieties in field conditions showing higher pepper yield. Similarly, Rafique and Ortas (2018) reported that G. mosseae and G. etunicatium inoculated pepper yield increased by $35.7 \%$ and $20.0 \%$, respectively. On clayey soil with containing different doses of phosphorus, G. macrocarpum and G. fasciculatum inoculated pepper fruit yield, shoot $\mathrm{P}, \mathrm{Zn}, \mathrm{Cu}, \mathrm{Mn}$ and $\mathrm{Fe}$ uptake of the plants increased significantly grown compared to those not infected (Sreenivasa et al., 1993). Janos (2007) reported that the yield response of crop plants to mycorrhiza inoculation or nutrient content, is a specific to plant trait, and controlled interactively by plant $\mathrm{x}$ mycorrhiza type $\mathrm{x}$ environment including agricultural management practices. The results of Pischl and Barber (2017) shown that AMF (arbuscular mycorrhizal fungi) may ameliorate the effects of temperature stress enhancing plants growth efficiency and nutrient content. Tanwar et al. (2013) results are shown that mycorrhiza inoculated pepper plant produced more spores compared to control applications, and higher spores were obtained from both in mycorrhizal inoculation with additionally $0.2 \mathrm{~g}$ super phosphate applications per pot. However, they found that there was a decrease in the number of spores with 0.4 and $0.8 \mathrm{~g} \mathrm{P}_{\text {pot }}^{-1}$ and mycorrhizal inoculation treatments. In Harran Plain, the climate is hot and dry, and the organic matter of the soils is low which all limits the productivity of these soils (Oztürkmen et al., 2020).

The aim of our study was to determine the interactive effect of mycorrhiza (G. mosseae) inoculation and phosphorous fertilizer application on the growth, yield, nutrient uptake quality components of pepper in a 3-year field experiment under semi-arid climatic conditions. 


\section{Materials and Methods}

The field experiment was carried out in South Eastern Project Research Institute, Şanliurfa province, Turkey $\left(36^{\circ} 47^{\prime}, 39^{\circ} 15^{\prime} \mathrm{E}, 36^{\circ} 40^{\prime}, 37^{\circ} 41^{\prime} \mathrm{N}\right)$ during 2013-2015. Long term annual air temperature was $18.3^{\circ} \mathrm{C}$, with an annual mean precipitation of $459.4 \mathrm{~mm}$ (from 1950 to 2016). Harran soil series texture was silty clay loam with a $\mathrm{pH}$ value of 7.6 (Table 1).

Table 1. Some physical and chemical properties of soils of the research site prior to experiment

\begin{tabular}{|c|c|c|c|}
\hline Soil Properties & 2013 & 2014 & 2015 \\
\hline Water saturation (\%) & 66 & 66 & 64 \\
\hline pH (1:1) & 8.0 & 7.6 & 7.3 \\
\hline $\operatorname{EC}\left(d_{S} m^{-1}\right)$ & 1.0 & 1.6 & 1.8 \\
\hline $\mathrm{CaCO}_{3}(\%)$ & 27.7 & 27.3 & 30.7 \\
\hline Phosphorus $\mathrm{P}_{2} \mathrm{O}_{5}\left(\mathrm{~kg} \mathrm{ha}^{-1}\right)$ & 31.3 & 26.9 & 38.5 \\
\hline Potassium $\mathrm{K}_{2} \mathrm{O}\left(\mathrm{kg} \mathrm{ha}^{-1}\right)$ & 1164 & 1371 & 1536 \\
\hline Organic Matter (\%) & 1.4 & 2.0 & 2.5 \\
\hline
\end{tabular}

Prior to experiment in order to exploit the residual fertilizers in the soil, wheat, barley and maize were grown in the experimental field.

\section{Seedling growth and mycorrhizal inoculation}

Red pepper (Capsicum annuum L.) (cv. İnan 3363) seeds were sown in plastic trays with $20 \mathrm{~cm}^{3}$ cells filled with a sterilized (at $121^{\circ} \mathrm{C}$ for $1 \mathrm{~h}$ ) peat and perlite mixture $(1: 1$, $\mathrm{V} / \mathrm{V}$ ). Glomus mosseae were inoculated to the trays at rate of 1000 spore/cell (three seedlings per cell). Mycorrhiza spores were directly placed below the seeds in each cell.

\section{Field experiment}

Three years experiments were conducted field of Harran series soil. The field experiment consists application of various phosphorus doses and mycorrhiza inoculation in factorial randomized complete blocks design with three replications. Four treatments used in the experiment were i) control (CK), ii) mineral P application (PA, $100 \mathrm{~kg}$ $\mathrm{P}_{2} \mathrm{O}_{5}$ ha $^{-1}$ ), iii) mycorrhiza inoculated during seedling period (SM; with Glomus mosseae) and iv) $\mathrm{P}$ fertilizer mycorrhiza inoculated treatment (PSM; $100 \mathrm{~kg} \mathrm{P}_{2} \mathrm{O}_{5} \mathrm{ha}^{-1}+$ Glomus mosseae). The size of plots was $15 \mathrm{~m}^{2}$, and the seedlings were planted at $70 \mathrm{~cm}$ inter-row and $40 \mathrm{~cm}$ intra-row distances. A total of $210 \mathrm{~kg} \mathrm{ha}^{-1}$ nitrogen was applied as ammonium nitrate $\left(\mathrm{NH}_{4} \mathrm{NO}_{3}\right)$. Half of the ammonium nitrate was applied during planting of seedlings, and the rest was applied during the fruit formation period. All the phosphorous fertilizer was applied before seedlings planting. Plants were irrigated via drip irrigation system, and approximately $1000 \mathrm{~mm} \mathrm{~m}^{-2}$ of water was applied throughout the growing period. The fruits were harvested when reached the maturity stages. The harvest was carried out in $6.2 \mathrm{~m}^{2}$ of each plot considering the edge effect. 


\section{Isolation and counting of mycorrhiza spores}

After the harvest of fruits, the rhizosphere soil and root samples were collected from each plot. The spores were counted according to the wet screening method (Gerdemann and Nicolson, 1963).

\section{Mycorrhizal infection}

Following plant roots separation from the soil and they were first washed with tap water and then with deionized water. The fresh weight of the plant roots was recorded after drying the excess water on the surface of the washed plant roots with drying pepper. The cleaned plant roots were prepared for mycorrhizal colonization by the method of Koske and Gemma (1989). Mycorrhizal root colonization was determined by the method of Giovenetti and Mosse (1980) under microscope with 40 to 60 magnification. Infection ratio in plant roots was determined using to the following equation;

$$
\begin{gathered}
\% \text { Infection ratio }=(\text { The number of roots inoculated } / \text { The number of } \\
\text { total roots }) \times 100
\end{gathered}
$$

\section{Nutrient analyses}

The first leaves in the upper position were collected during the fruit formation stage to determine the mineral nutrient contents plant leaves were washed with deionized water and dried at $70{ }^{\circ} \mathrm{C}$. The dried samples were grounded and were digested in nitric acid. The volumes of dissolved samples were completed to $20 \mathrm{ml}$ with deionized water. Macro and micro element concentrations were determined using the Atomic Absorption Spectrophotometer which was equipped with an Electro Thermal Temperature Controller and a VGA 77 (Vapor Generator Apparatus) apparatus. P was determined by the method of Olsen and Dean (1965).

\section{Quality analysis in pepper fruits}

The matured and harvested fruit size was measured in 20 fruits that represent the experiment from each plot. Vitamin $\mathrm{C}$ of fruit samples was measured by titrimetric method (Association of Vitamin Chemists, 1951) and $\mathrm{pH}$ was measured by a $\mathrm{pH}$ meter. Dry matter content was determined by a refractometer (IFJU, 1968).

\section{Statistical analysis}

The effects of phosphorus and mycorrhiza treatments on yield and yield components, spore counts, nutrient contents and all other parameters were assessed by a two-way variance analysis (ANOVA). When ANOVA indicated a significant difference, the least significant difference (LSD) post hoc test $(\mathrm{P}>0.05)$ was used to distinguish significant treatments. The statistical analysis was performed using SPSS 21 software (SPSS Inc., Chicago, IL, USA).

\section{Results}

\section{Fruit yield and dry matter content}

The effects of treatments on fresh fruit yield were significantly different between the years (Fig. 1). The treatments on yield and all other traits were not significant in 2013, 
while the fresh fruit yield was significantly increased in 2014 only with PA application and the highest yield in 2015 was obtained in PSM application treatment. In 2015, yield in SM and PSM treatments increased by 11 and $25 \%$ compared to the control. Dry fruit yield values in different years also were some similar to the fresh weight values. The differences in dry fruit yield obtained for 2013 was not statistically significant. In 2014, phosphorus and $\mathrm{P} * \mathrm{M}$ interaction significantly increase $(\mathrm{p}<0.015$ and, $\mathrm{p}<0.032$ respectively) yield (Table 2). However, the highest dry matter yield in 2015 was obtained in PSM and SM treatments. In 2015, the yield values from high to low were as follow; $\mathrm{PSM}>\mathrm{SM}>\mathrm{PA}=\mathrm{CK}$. The yield increase in SM and PSM treatments compared to control was 19 and 28\% higher, respectively. In 2015 experiment, mycorrhiza inoculation and phosphorus application significantly increase the yield $(\mathrm{p}<0.007, \mathrm{p}<0.02$, respectively). Plant height fruit vitamin and $\mathrm{pH}$ content were measured and treatments did not make any significant differences (Table 3).
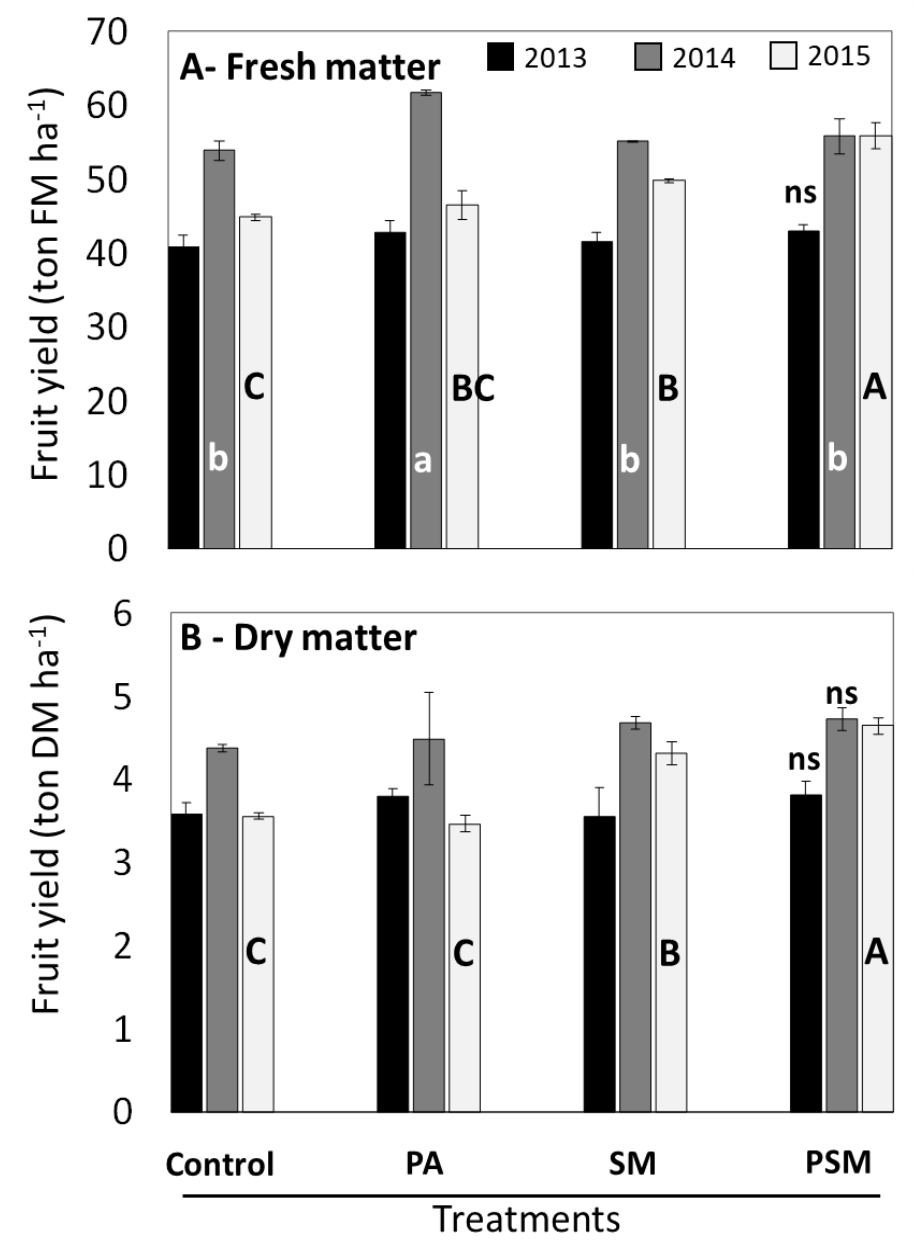

Figure 1. The effect of mycorrhizal inoculation on dry (A) and fresh fruit (B) yield $\left(\mathrm{kg} \mathrm{ha}^{-1}\right)$. i) control (CK), ii) mineral P applied treatment (PA, $\left.100 \mathrm{~kg}_{2} \mathrm{O}_{5} \mathrm{ha}^{-1}\right)$, iii) mycorrhiza inoculated treatment (SM; with Glomus mosseae) and iv) P fertilizer+mycorrhiza inoculated treatment (PSM; $100 \mathrm{~kg} \mathrm{P}_{2} \mathrm{O}_{5} \mathrm{ha}^{-1}+$ Glomus mosseae). Error bars show the standard error of each treatment $(n=3)$. Capital or small letters indicates statistical differences $(P<0.05)$ within years. $n s$ indicates not-significant 
Table 2. Significant of $P$-values (probability) from analysis of variance for different plant parameters

\begin{tabular}{c|c|c|c|c|c|c|c|c|c}
\hline Year & Treat & Df & Yield & Plant Height & Fruit vitamin C & Fruit pH & Fruit dry matter & Root infection rate Mycorrhizal spore density \\
\hline \multirow{2}{*}{2013} & $\mathrm{~m}$ & 1 & $\mathrm{~ns}$ & 0.8028 & 0.7517 & 0.8986 & 0.7895 & $* * *$ & 0.7035 \\
& $\mathrm{p}$ & 1 & $\mathrm{~ns}$ & $*$ & 0.6099 & 0.5290 & 0.6897 & 0.2555 & 0.9813 \\
& $\mathrm{~m} * \mathrm{p}$ & 1 & $\mathrm{~ns}$ & 0.3926 & 0.9566 & 0.5290 & 0.7895 & 0.2555 & 0.3816 \\
& $\mathrm{~m}$ & 1 & $\mathrm{~ns}$ & 0.1762 & 0.7057 & 0.9839 & 0.1403 & 0.0088 & $*$ \\
2014 & $\mathrm{p}$ & 1 & $* *$ & 0.9072 & 0.7622 & 0.0953 & 0.4012 & $*$ & 0.0851 \\
& $\mathrm{~m} * \mathrm{p}$ & 1 & $*$ & 0.0751 & 0.5469 & 0.0786 & 0.4012 & 0.8243 & $* .4015$ \\
& $\mathrm{~m}$ & 1 & $* * *$ & 0.1222 & 0.5060 & 0.9655 & $* *$ & $* * *$ & $*$ \\
& $\mathrm{p}$ & 1 & $* *$ & 0.5803 & 0.4452 & 0.1044 & 0.1630 & $*$ & 0.2148 \\
& $\mathrm{~m} * \mathrm{p}$ & 1 & $\mathrm{~ns}$ & 0.3650 & $* *$ & 0.9655 & 0.8044 & 0.3466 & 0.3641 \\
\hline
\end{tabular}

\begin{tabular}{c|c|c|c|c|c|c|c|c|c|c|c|c|c}
\hline Year & Treat & Df & $\mathbf{N}$ & $\mathbf{P}$ & $\mathbf{K}$ & $\mathbf{C a}$ & $\mathbf{M g}$ & $\mathbf{F e}$ & $\mathbf{Z n}$ & $\mathbf{M n}$ & $\mathbf{C u}$ & $\mathbf{B}$ & $\mathbf{N a}$ \\
\hline \multirow{3}{*}{2013} & $\mathrm{~m}$ & 1 & $\mathrm{~ns}$ & 0.2638 & 0.9389 & 0.8945 & 0.5302 & 0.2193 & 0.1036 & 0.3840 & 0.0789 & 0.8927 & 0.7029 \\
& $\mathrm{p}$ & 1 & $\mathrm{~ns}$ & 0.4295 & 0.1187 & 0.3223 & 0.1529 & 0.4948 & 0.6089 & 0.3110 & 0.5865 & 0.2944 & 0.1205 \\
& $\mathrm{~m} * \mathrm{p}$ & 1 & $\mathrm{~ns}$ & 0.5357 & 0.9529 & 0.1965 & 0.2680 & 0.9766 & 0.7995 & 0.2411 & 0.9711 & 0.3763 & 0.3553 \\
& $\mathrm{~m}$ & 1 & $\mathrm{~ns}$ & 0.5214 & 0.5496 & 0.6049 & 0.6216 & 0.9604 & 0.6917 & 0.3963 & 0.9676 & 0.7982 \\
2014 & $\mathrm{p}$ & 1 & $\mathrm{~ns}$ & 0.9260 & 0.2831 & 0.1128 & 0.1788 & 0.6376 & 0.1124 & 0.0774 & 0.2203 & 0.0727 & 0.1104 \\
& $\mathrm{~m}$ & 1 & $\mathrm{~ns}$ & 0.5214 & 0.4784 & 0.7725 & 0.6782 & 0.8974 & 0.2057 & 0.6537 & 0.1523 & 0.9688 & 0.5788 \\
& $\mathrm{~m}$ & 1 & $\mathrm{~ns}$ & 0.3533 & 0.8818 & 0.5703 & 0.9407 & 0.7796 & 0.6305 & 0.6985 & 0.3808 & 0.4315 & 0.6076 \\
2015 & $\mathrm{p}$ & 1 & $\mathrm{~ns}$ & 0.8487 & 0.5703 & 0.6965 & 0.5806 & 0.3594 & 0.8167 & 0.7206 & 0.6362 & 0.6247 & 0.0964 \\
& $\mathrm{~m}$ & 1 & $\mathrm{~ns}$ & 0.7038 & 0.5703 & 0.7601 & 0.9407 & 0.8706 & 0.7936 & 0.8621 & 0.8530 & 0.4364 & 0.2069 \\
\hline
\end{tabular}

$* \mathrm{P}<0.5, * * \mathrm{P}<0.01, * * * \mathrm{p}<0.001$ indicates statistical differences within treatment, ns indicates not-significant 
Table 3. The effect of mycorrhizal inoculation on yield, plant height, quality parameters and mycorrhizal root infection parameters. Treatment abbreviations are; i) control (CK), ii) mineral P applied treatments (PA, $100 \mathrm{~kg} \mathrm{P}_{2} \mathrm{O}_{5}$ ha ${ }^{-1}$ ), iii) mycorrhiza inoculated treatment (SM; with Glomus mosseae) and iv) P fertilizer + mycorrhiza inoculated treatment (PSM; $100 \mathrm{~kg} \mathrm{P}_{2} \mathrm{O}_{5} \mathrm{ha}^{-1}+$ Glomus mosseae)

\begin{tabular}{|c|c|c|c|c|c|c|c|c|}
\hline Year & Treat & Fresh yield & $\begin{array}{l}\text { Yield (dry } \\
\text { weight) }\end{array}$ & Plant Height & Fruit vitamin C & Fruit pH & $\begin{array}{c}\text { Fruit dry matter } \\
\text { content }\end{array}$ & Root infection rate \\
\hline & & ton $\mathrm{ha}^{-1}$ & ton $\mathrm{ha}^{-1}$ & $\mathrm{~cm}$ & $\mathrm{mg} 100 \mathrm{~g}^{-1}$ & & $\%$ (brix) & $\%$ \\
\hline 2013 & CK & $40.9 \pm 1.5^{\mathrm{ns}}$ & $3.6 \pm 0.1^{\mathrm{ns}}$ & $61.7 \pm 2.3^{\mathrm{ns}}$ & $136.9 \pm 22.9^{\mathrm{ns}}$ & $5.09 \pm 0.01^{\mathrm{ns}}$ & $8.80 \pm 0.58^{\mathrm{ns}}$ & $0.0 \pm 0.0^{\mathrm{ns}}$ \\
\hline 2013 & PA & $42.7 \pm 1.6$ & $3.8 \pm 0.1$ & $65.3 \pm 1.2$ & $142.9 \pm 7$ & $5.09 \pm 0.01$ & $8.87 \pm 0.13$ & $0.0 \pm 0.0$ \\
\hline 2013 & $\mathrm{SM}$ & $41.5 \pm 1.2$ & $3.6 \pm 0.3$ & $58.7 \pm 2.3$ & $132.1 \pm 6.6$ & $5.11 \pm 0.04$ & $8.53 \pm 0.59$ & $30.0 \pm 5.8$ \\
\hline 2013 & PSM & $43.0 \pm 0.9$ & $3.8 \pm 0.2$ & $67.0 \pm 3.8$ & $139.4 \pm 2.6$ & $5.08 \pm 0.02$ & $8.87 \pm 0.48$ & $10.0 \pm 5.8$ \\
\hline 2014 & $\mathrm{CK}$ & $53.8 \pm 1.4^{\mathrm{B}}$ & $4.4 \pm 0.0^{\mathrm{ns}}$ & $71.9 \pm 1.6^{\mathrm{ns}}$ & $132.3 \pm 20.6^{\mathrm{ns}}$ & $5.06 \pm 0.03^{\mathrm{ns}}$ & $8.13 \pm 0.15^{\mathrm{ns}}$ & $10.0 \pm 0.0^{\mathrm{B}}$ \\
\hline 2014 & PA & $61.7 \pm 0.4^{\mathrm{A}}$ & $4.5 \pm 0.6$ & $75.1 \pm 0.8$ & $121.1 \pm 10.5$ & $5.37 \pm 0.11$ & $7.27 \pm 0.89$ & $23.3 \pm 3.3 \mathrm{AB}$ \\
\hline 2014 & SM & $55.0 \pm 0.1^{\text {в }}$ & $4.7 \pm 0.1$ & $72.9 \pm 0.4$ & $129.5 \pm 3.9$ & $5.22 \pm 0.03$ & $8.50 \pm 0.15$ & $33.3 \pm 6.7^{\mathrm{AB}}$ \\
\hline 2014 & PSM & $55.7 \pm 2.4^{\mathrm{AB}}$ & $4.7 \pm 0.1$ & $69.3 \pm 2.8$ & $133.3 \pm 4.6$ & $5.21 \pm 0.11$ & $8.50 \pm 0.35$ & $46.7 \pm 12.0^{\mathrm{A}}$ \\
\hline 2015 & $\mathrm{CK}$ & $44.8 \pm 0.5^{\mathrm{b}}$ & $3.6 \pm 0.0^{b}$ & $67.3 \pm 0.7^{\mathrm{ns}}$ & $105.1 \pm 5.0^{\mathrm{ns}}$ & $4.90 \pm 0.03^{\mathrm{ns}}$ & $7.93 \pm 0.07 \mathrm{~ns}$ & $10.0 \pm 5.8^{c}$ \\
\hline 2015 & PA & $46.4 \pm 1.9^{\mathrm{b}}$ & $3.5 \pm 0.1^{b}$ & $63.3 \pm 1.8$ & $138.8 \pm 11.6$ & $4.97 \pm 0.05$ & $7.47 \pm 0.29$ & $16.7 \pm 6.7^{\mathrm{bc}}$ \\
\hline 2015 & SM & $49.7 \pm 0.3^{b}$ & $4.3 \pm 0.1^{\mathrm{a}}$ & $69.3 \pm 4.8$ & $126.1 \pm 10.2$ & $4.90 \pm 0.03$ & $8.67 \pm 0.24$ & $36.7 \pm 3.3 \mathrm{ab}$ \\
\hline 2015 & PSM & $55.8 \pm 1.8^{\mathrm{a}}$ & $4.6 \pm 0.1^{\mathrm{a}}$ & $70.3 \pm 0.3$ & $106.0 \pm 5.0$ & $4.97 \pm 0.03$ & $8.33 \pm 0.35$ & $53.3 \pm 3.3^{\mathrm{a}}$ \\
\hline
\end{tabular}

Capital or non-capital symbols indicates statistical differences within treatment in each year at $\mathrm{P}<0.05$, ns indicates not-significant 


\section{The number of spores}

The number of spores in $10 \mathrm{~g}$ soil in the mycorrhiza and phosphorus treatments were given in Fig. 2. The number of spores mycorrhiza inoculated treatments was generally higher than those without inoculation. The number of spores in PSM application was 2.7, 29.3 and 26.7 in $10 \mathrm{~g}$ dry soil in 2013, 2014 and 2015, respectively. The values in SM applications were lower than the values obtained in PSM applications (except in 2013), while higher than those determined in CK and PA applications. The number of spores in SM and PSM treatments in 2015 was 143 and 247\% higher compared to the number of spores counted in control, respectively. Phosphorus application alone in 2014 and 2015 also significantly increased $(\mathrm{p}<0.002, \mathrm{p}<0.003$, respectively) the number of spores compared to the control.
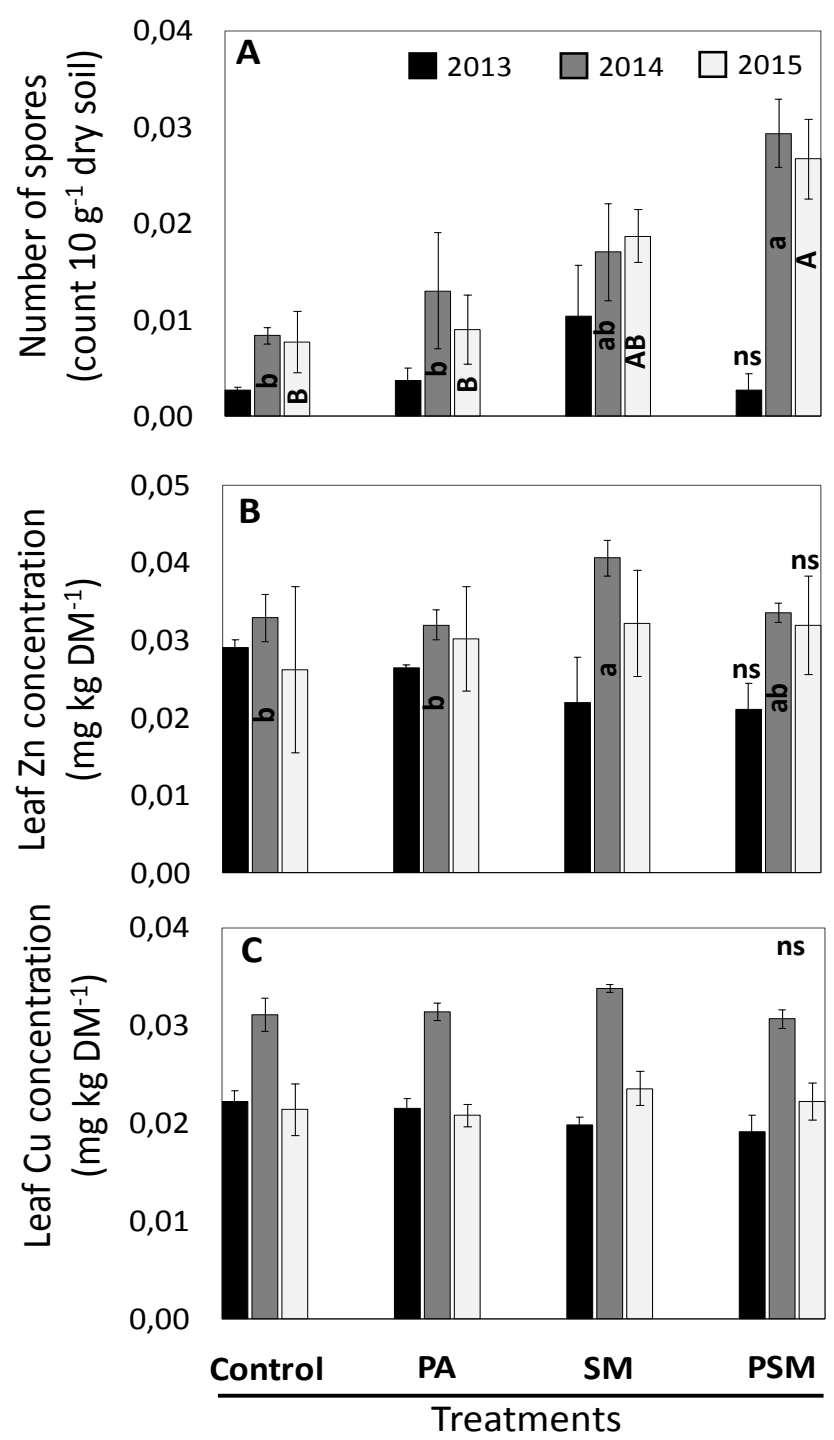

Figure 2. The effect of mycorrhizal inoculation on the number of spores (A), leaf $\mathrm{Zn}(B)$ and $\mathrm{Cu}$

(C) concentrations. Treatment abbreviations are; $i)$ control $(C K)$, ii) mineral $P$ applied treatments (PA, $100 \mathrm{~kg} \mathrm{P}_{2} \mathrm{O}_{5} \mathrm{ha}^{-1}$ ), iii) mycorrhiza inoculated treatment (SM; with Glomus mosseae) and iv) P fertilizer + mycorrhiza inoculated treatment (PSM; $100 \mathrm{~kg} \mathrm{P}_{2} \mathrm{O}_{5} \mathrm{ha}^{-1}+$ Glomus mosseae). Error bars show the standard error of each treatment $(n=3)$. Capital or small letters indicates statistical differences $(P<0.5)$ within years. $n$ s indicates not-significant 


\section{Plant nutrients}

Nutrient concentrations of the leaves in mycorrhiza and phosphorus applications are presented in Table 2. The N, P, K, Ca, Mg, Fe, Mn, Cu, B and $\mathrm{Na}$ content of leaves in 2013, 2014 and 2015 were not statistically different among the treatments (Table 2 and Table 4). The effect of applications on leaf $\mathrm{Zn}$ concentration was not statistically significant. Leaf Zn concentration in 2014 and 2015 increased significantly in SM and PSM treatments where mycorrhiza inoculated (statistically significant only in 2014). In contrast, the leaf $\mathrm{Zn}$ concentration in 2013 was not significantly changed with the treatments. The mean leaf $\mathrm{Zn}$ concentration of three-year was $31.7 \mathrm{mg} \mathrm{Zn} \mathrm{kg}^{-1}$ in SM treatment and $29.3 \mathrm{mg} \mathrm{Zn} \mathrm{kg}^{-1}$ in control. The leaf $\mathrm{Zn}$ concentration in 2014 was $40.6 \mathrm{mg}$ $\mathrm{Zn} \mathrm{kg}^{-1}$ in SM application, while it was $32.8 \mathrm{mg} \mathrm{Zn} \mathrm{kg}^{-1}$ in control (Fig. 2). The leaf $\mathrm{Zn}$ concentration in 2014 was $24 \%$ higher than the control. When the same treatments were compared, the difference in 2015 was determined as 23\%. Similar to the $\mathrm{Zn}$ concentrations, the leaf $\mathrm{Cu}$ concentrations also differed between the treatments, although the values were not significantly different. The leaf $\mathrm{Cu}$ concentrations in 2014 and 2015 were increased in mycorrhiza inoculated treatments; however, the increase is not statistically significant.

The mean yield (dry) values in 2014 were higher compared to 2013 and 2015. Similarly, the $\mathrm{Cu}$ content of the leaves in 2014 was higher than the $\mathrm{Cu}$ content determined in 2013 and 2015. In the present work the number of spores and the yield had a significant positive correlation (Fig. 3). Also there is a relationship in between root colonization and yield increases during three years' data.

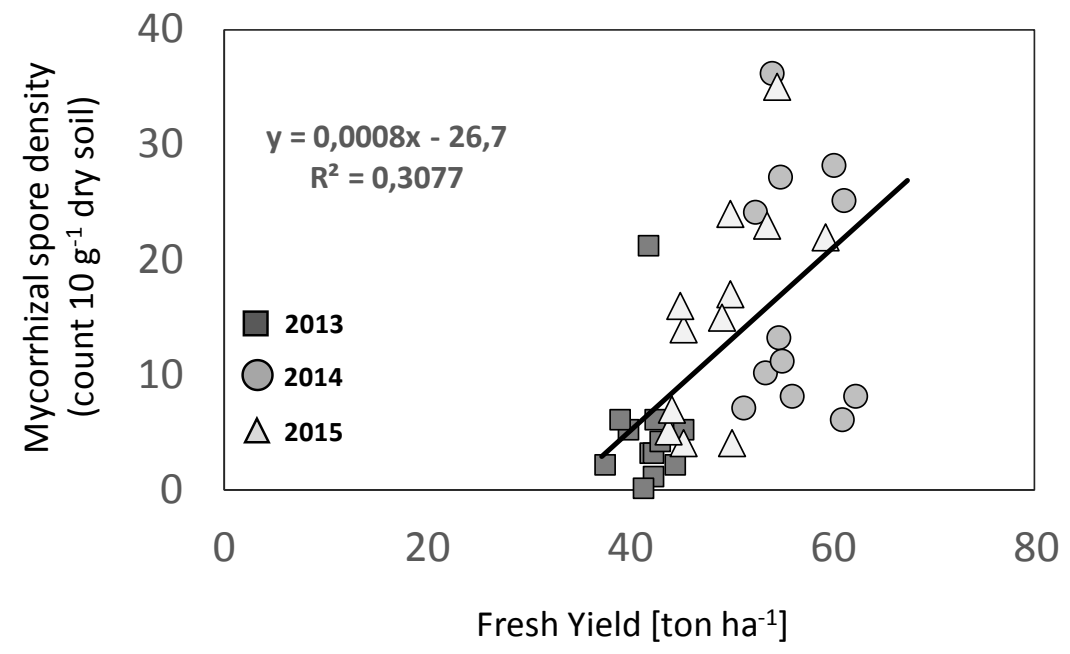

Figure 3. The relationship between mycorrhizal spore density and fresh fruit yield

\section{Mycorrhizal colonization}

In 2013, mycorrhizal root colonization (\%) was low and not significant, however in 2014 and 2015 mycorrhizal root colonization were high and statistically significant. Especially in year 2015, without colonization root colonization was determined. With SM (G. mosseae) treatment $36.7 \%$ and with P fertilizer + mycorrhiza inoculated treatment $53.3 \%$ of root colonization were determined (Fig. 4). 
Table 4. The effects of mycorrhiza inoculation on plant nutrient concentrations. Treatment abbreviations: i) control (CK), ii) mineral P applied treatments (PA, $100 \mathrm{~kg} \mathrm{P}_{2} \mathrm{O}_{5} \mathrm{ha}^{-1}$ ), iii) mycorrhiza inoculated treatment ( $\mathrm{SM}$; with Glomus mosseae) and iv) P fertilizer + mycorrhiza inoculated treatment (PSM; $100 \mathrm{~kg} \mathrm{P}_{2} \mathrm{O}_{5} \mathrm{ha}^{-1}+$ Glomus mosseae)

\begin{tabular}{|c|c|c|c|c|c|c|c|c|c|c|c|c|}
\hline \multirow[t]{2}{*}{ Year } & \multirow[t]{2}{*}{ Treat } & $\mathbf{N}$ & $\mathbf{P}$ & $\mathbf{K}$ & $\mathbf{C a}$ & Mg & $\mathbf{F e}$ & Zn & Mn & $\mathbf{C u}$ & B & $\mathbf{N a}$ \\
\hline & & \multicolumn{5}{|c|}{$\%$} & \multicolumn{6}{|c|}{$\mathrm{mg} \mathrm{kg}^{-1}$} \\
\hline 2013 & $\mathrm{CK}$ & $4.92 \pm 0.25 \mathrm{~ns}$ & $0.24 \pm 0.02$ ns & $5.06 \pm 0.45^{\mathrm{ns}}$ & $2.39 \pm 0.09 \mathrm{~ns}$ & $0.70 \pm 0.04$ ns & $66.0 \pm 12.4^{\mathrm{ns}}$ & $29.1 \pm 1.0^{\mathrm{ns}}$ & $139 \pm 6^{\mathrm{ns}}$ & $22.2 \pm 1.6^{\mathrm{ns}}$ & $64.0 \pm 3.6^{\mathrm{ns}}$ & $83.0 \pm 12.8^{\mathrm{ns}}$ \\
\hline 2013 & PA & $4.73 \pm 0.12$ & $0.21 \pm 0.01$ & $4.07 \pm 0.46$ & $2.46 \pm 0.10$ & $0.68 \pm 0.01$ & $61.1 \pm 2.0$ & $26.4 \pm 0.4$ & $142 \pm 5$ & $21.6 \pm 1.0$ & $62.9 \pm 2.0$ & $76.4 \pm 4.0$ \\
\hline 2013 & SM & $4.65 \pm 0.28$ & $0.21 \pm 0.02$ & $5.07 \pm 0.84$ & $2.71 \pm 0.33$ & $0.83 \pm 0.11$ & $57.1 \pm 2.6$ & $21.9 \pm 5.8$ & $181 \pm 35$ & $19.8 \pm 0.8$ & $70.6 \pm 10.6$ & $95.0 \pm 10.9$ \\
\hline 2013 & PSM & $4.84 \pm 0.14$ & $0.20 \pm 0.02$ & $4.14 \pm 0.29$ & $2.20 \pm 0.21$ & $0.64 \pm 0.07$ & $52.7 \pm 1.8$ & $21.0 \pm 3.4$ & $136 \pm 14$ & $19.1 \pm 1.7$ & $58.0 \pm 4.5$ & $71.3 \pm 2.5$ \\
\hline 2014 & $\mathrm{CK}$ & $3.80 \pm 0.06^{\mathrm{ns}}$ & $0.21 \pm 0.02^{\mathrm{ns}}$ & $7.34 \pm 0.56^{\mathrm{ns}}$ & $2.74 \pm 0.56^{\mathrm{ns}}$ & $1.27 \pm 0.31^{\mathrm{ns}}$ & $111.7 \pm 7.5^{\mathrm{ns}}$ & $32.8 \pm 3.0 \mathrm{~B}$ & $131 \pm 21^{\text {ns }}$ & $31.1 \pm 1.7^{\text {ns }}$ & $72.4 \pm 5.5^{\text {ns }}$ & $65.9 \pm 18.3^{\mathrm{ns}}$ \\
\hline 2014 & PA & $3.77 \pm 0.15$ & $0.20 \pm 0.01$ & $7.04 \pm 0.41$ & $2.20 \pm 0.04$ & $1.06 \pm 0.05$ & $106.1 \pm 8.9$ & $31.9 \pm 1.9 \mathrm{~B}$ & $111 \pm 3$ & $31.4 \pm 0.9$ & $63.5 \pm 4.9$ & $40.0 \pm 14.6$ \\
\hline 2014 & SM & $3.58 \pm 0.22$ & $0.21 \pm 0.03$ & $8.33 \pm 0.93$ & $2.65 \pm 0.46$ & $1.25 \pm 0.25$ & $110.0 \pm 10.0$ & $40.6 \pm 2.3 \mathrm{~A}$ & $131 \pm 14$ & $33.8 \pm 0.4$ & $72.0 \pm 1.1$ & $83.9 \pm 34.2$ \\
\hline 2014 & PSM & $3.79 \pm 0.20$ & $0.22 \pm 0.01$ & $6.95 \pm 0.89$ & $1.90 \pm 0.05$ & $0.87 \pm 0.02$ & $106.8 \pm 9.1$ & $33.6 \pm 1.2 \mathrm{AB}$ & $100 \pm 1$ & $30.7 \pm 0.9$ & $63.5 \pm 3.9$ & $33.2 \pm 10.1$ \\
\hline 2015 & $\mathrm{CK}$ & $4.19 \pm 0.24^{\mathbf{n s}}$ & $0.25 \pm 0.02^{\mathrm{ns}}$ & $2.72 \pm 0.26^{\mathrm{ns}}$ & $3.94 \pm 0.55^{\mathrm{ns}}$ & $1.05 \pm 0.03^{\mathrm{ns}}$ & $203.3 \pm 27.9 \mathrm{~ns}$ & $26.1 \pm 10.7^{\mathrm{ns}}$ & $170 \pm 21$ ns & $21.4 \pm 2.7^{\mathrm{ns}}$ & $56.4 \pm 21.9^{\mathrm{ns}}$ & $51.9 \pm 17.1^{\mathrm{ns}}$ \\
\hline 2015 & PA & $3.86 \pm 0.08$ & $0.26 \pm 0.01$ & $2.72 \pm 0.37$ & $3.99 \pm 0.29$ & $1.09 \pm 0.08$ & $229.9 \pm 13.3$ & $30.1 \pm 6.7$ & $173 \pm 14$ & $20.8 \pm 1.2$ & $41.3 \pm 5.4$ & $95.6 \pm 7.1$ \\
\hline 2015 & SM & $4.03 \pm 0.07$ & $0.28 \pm 0.02$ & $2.50 \pm 0.34$ & $3.98 \pm 0.54$ & $1.05 \pm 0.08$ & $214.0 \pm 21.0$ & $32.2 \pm 6.8$ & $174 \pm 18$ & $23.6 \pm 1.8$ & $37.7 \pm 1.6$ & $77.5 \pm 18.9$ \\
\hline 2015 & PSM & $3.95 \pm 0.15$ & $0.27 \pm 0.01$ & $2.86 \pm 0.22$ & $4.33 \pm 0.54$ & $1.10 \pm 0.13$ & $232.8 \pm 28.1$ & $31.9 \pm 6.4$ & $184 \pm 19$ & $22.2 \pm 1.9$ & $41.2 \pm 3.1$ & $84.3 \pm 4.6$ \\
\hline
\end{tabular}

Capital or non-capital symbols indicates statistical differences within treatment in each year at $\mathrm{P}<0.5$, ns indicates not-significant 


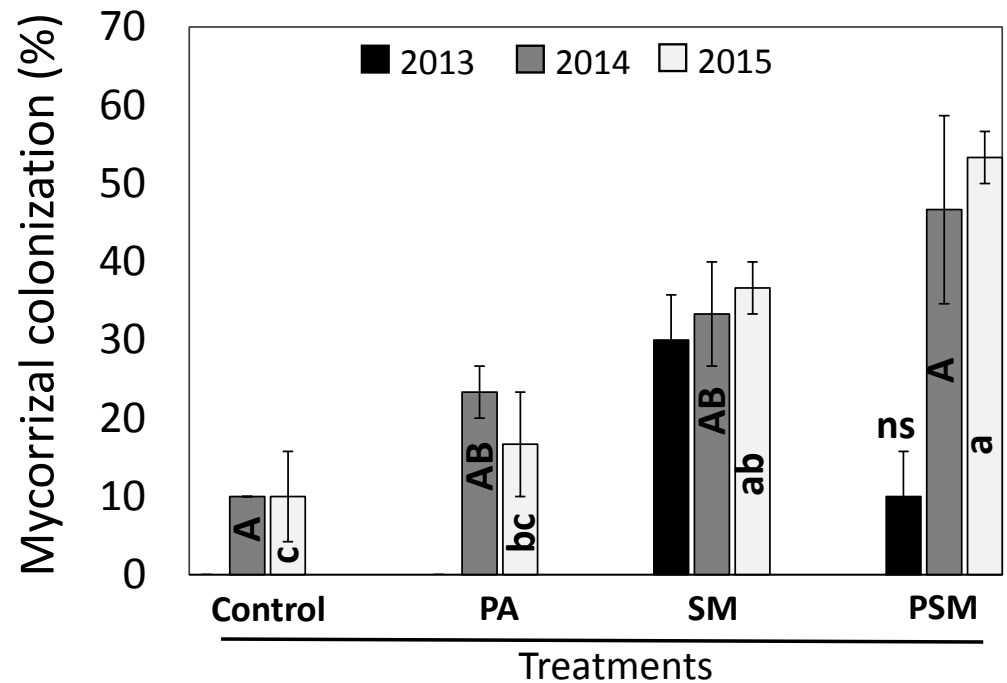

Figure 4. The effect of mycorrhizal inoculation on mycorrhizal root colonization (\%). Treatment abbreviations are; i) control (CK), ii) mineral $P$ applied treatment $\left(\mathrm{PA}, 100 \mathrm{~kg} \mathrm{P}_{2} \mathrm{O}_{5}\right.$ $h a^{-1}$ ), iii) mycorrhiza inoculated treatment (SM; with Glomus mosseae) and iv) P fertilizer + mycorrhiza inoculated treatment (PSM; $100 \mathrm{~kg} \mathrm{P}_{2} \mathrm{O}_{5} \mathrm{ha}^{-1}+$ Glomus mosseae). Error bars show the standard error of each treatment $(n=3)$. Capital or small letters indicates statistical differences $(P<0.5)$ within years. ns indicates not-significant

\section{Discussion}

Soil microbial dynamics (such as AMF) has large impact on soil fertility and nutrient availability to the arable crops. This 3-year field study showed that there is an interactive effect of mycorrhiza ( $G$. mosseae) and phosphorous fertilizer application on the growth and yield of pepper. In 2014 and 2015, mycorrhizal inoculation increased pepper yield significantly. The highest dry matter yield was determined in PSM and SM treatments in 2015 (Fig. 1). Here, the fresh fruit yield in 2015 was ranked as PSM $>$ SM $>$ PA $=$ CK, respectively. The yield increase in SM and PSM treatments compared to control was 19 and $28 \%$ in 2015, respectively indicating interactive effect of P supply and AMF on yield. In line with the present experiments, authors reported significant impact of AMF inoculation on pepper yield (around 8-35\%) (Rafique and Ortas, 2018; Ortas, 2019b). Unlike to 2015, AMF had no significant effect on pepper plant growth in 2013. On the other hand, the positive effect of mycorrhiza inoculation on pepper plant yield was also reported by Sanders et al. (2003) and Al Raddad (1987). Wang et al. (2020) concluded that the nutrient uptake and growth of plants inoculated were higher compared to the noninoculated control plants. In line with the growth parameters, the effect of AMF and P application on the number of spores in 2013 was also not significant, however, the number of spores in 2014 and 2015 was statistically higher in P and AMF treatments as compared to the control. In general, colonization of mycorrhiza is an important trait affecting plant nutrient status due to the active role in nutrient transport and utilization in higher plants (Barea et al., 1990).

The results of this three-year field study clearly showed that the effect of mycorrhiza inoculation on pepper yield varied between the years likely due to the variation in climatic conditions. Previously Douds et al. (2017) reported that the response of mycorrhizal 
inoculation appeared to be inversely related to the number of propagules of AM fungi in the indigenous community of the field soil.

Zn deficiency, which frequently occurs in alkaline soils of semi-arid climates, can be partially overcome by increasing the mycorrhizal activity. One of the benefits of forming AMF for plants is enhanced $\mathrm{Zn}$ uptake for most crop species as summirized in meta-analysis (xx). In our study, mycorrhiza application significantly increased the $\mathrm{Zn}$ contents of the leaves (significant only in 2014) (Fig. 2). Contribution of AMF to plant Zn uptake was also reported by Coccina et al. (2019). Although, it is commonly accepted that mycorrhiza increase Zn uptake of crop plants (Jansa et al., 2003), the physiological and molecular mechanisms controlling this interaction is not well understood specifically in semi-arid climate conditions. Plants colonized by AMF have two soil nutrient uptake pathways: (1) directly via the root epidermis, and (2) via fungal structures that form the mycorrhizal pathway of uptake (Smith et al., 2003). Coccina et al. (2019) concluded that mycorrhizal pathway of uptake may be the dominant pathway, however, it is also dependent on plant species, as well as available soil $\mathrm{Zn}$. It is clear that there is no single mycorrhizal effect on plant communities (Allen, 1991). As effect of AMF on plant performance is not solely depends on $\mathrm{P}$ availability, it is necessary to study how AMF inoculation would affect other nutrients specifically in alkaline soils.

The differences in nutrient content and the effectiveness of mycorrhiza inoculation can be attributed to the significant impact of the climate effect that differs every year. The focus of future research will be the identification and selection of existing mycorrhiza species in nature, reproduction and successful application of selected mycorrhiza, and developing agricultural techniques that will increase the effectiveness of natural mycorrhiza (An et al., 2010).

\section{Conclusion}

Overall, our study clearly showed that AMF inoculation in conjunction with P fertilizer application can enhance crop yield (during high yielding seasons) not only via enhanced $\mathrm{P}$ uptake but also affecting the uptake of other plant nutrients such as $\mathrm{Zn}$. The AMF have the ability to improve plant nutrient status of the host plant through triggered uptake of several soil mineral nutrients. As partly shown in our study, this is especially relevant for the uptake of relatively immobile elements (e.g. P, $\mathrm{Zn}, \mathrm{Cu}$,). Another important finding of our study was that number of spore and fresh pepper yield was significantly correlated. This revealed that number of spores can be used as a productivity indicator for pepper cultivation. On the other hand, we need further research to select efficient mycorrhiza species in nature that are effective specifically for irrigated high yielding crop species in semi-arid regions.

\section{REFERENCES}

[1] Aggangan, N. S., Dell, B., Malajczuk, N., Dela Cruz, R. E. (1999): Comparative effect of ectomycorrhizal inoculation and fertilization on Eucalyptus urophylla S. T. Blake five years after outplanting in a marginal soil in the Philippines. - In: Dela Cruz, R. E. (ed.) Proc. of $7^{\text {th }}$ International BIO-REFOR Workshop, Manila, Philippines, Nov. 3-5, 1998, pp. 78-82. University of Tokyo, Japan. 
[2] Al-Amri, S. M. (2019): Mitigation of salinity stress of pepper (Capsicum annuum L.) by arbuscular mycorrhizal fungus, Glomus constrictum. - Applied Ecology and Environmental Research 17(4): 9965-9978.

[3] Allen, M. F. (1991): The Ecology of Mycorrhizae. - Cambridge University Press, Cambridge.

[4] Almaca, A., Almaca, N. D., Söylemez, S., Ortaș, I. (2013): The effects of mycorrhizal species and different doses of phosphorus on pepper (Capsicum annuum L.) yield and development under field conditions. - Journal of Food, Agriculture and Environment 11(34): 647-651.

[5] Al-Raddad, A. M. (1987): Effect of VA mycorrhizal isolates on growth of tomato, eggplant and pepper in field soil. - Dirasat (Jordan) 14(11): 161-168.

[6] An, G. H., Kobayashi, S., Enoki, H., Sonobe, K., Muraki, M., Karasawa, T., Ezawa, T. (2010): How does arbuscular mycorrhizal colonization vary with host plant genotype? An example based on maize (Zea mays) germplasms. - Plant Soil 327: 441-453.

[7] Association of Vitamin Chemists. (1951): Methods of Vitamin Assay. - Association of Vitamin Chemists, Interscience Publishers, New York, USA.

[8] Barea, J. M., Salamanca, C. P., Herrera, M. A., Roldan-Fajardo, B. E. (1990): The role of VA mycorrhiza at improving $\mathrm{N}_{2}$-fixation by woody legumes in arid zones. - In: Werner, D., Muller, P. (eds.) Fast-growing trees and nitrogen-fixing trees. - Gustav Fischer, Stuttgart, pp. 303-311.

[9] Coccina, A., Cavagnaro, T. R., Pellegrino, E., Ercoli, L., McLaughlin, M. J., WattsWilliams, S. J. (2019): The mycorrhizal pathway of zinc uptake contributes to zinc accumulation in barley and wheat grain. - BMC Plant Biology 19: 133-147.

[10] Douds, D. D., Carr, E., Shenk, J. E., Ganser, S. (2017): Positive yield response of eggplant (Solanum melongena L.) to inoculation with AM fungi produced on-farm. - Horticulture 224: 48-52.

[11] FAO. (2018): http://www.fao.org.415-424.

[12] Gerdemann, J. W., Nicolson, T. H. (1963): Spores of mycorrhizal endogamy species extracted from soil by wet sieving and decanting. - Trans Brit. Mycol. Soc. 46: 235-244.

[13] Gerdemann, J. W., Trappe, J. M. (1974): The Endogonacea in the Pacific Northwest. Mycol. Mem. 5: 1-76.

[14] Gilmore, A. E. (1968): Phycomycetous mycorrhizal organisms collected by open-pot culture methods. - Hilgardia 39: 87-105.

[15] Giovannetti, M., Mosse, B. (1980): An evaluation of techniques for measuring vesiculararbuscular mycorrhiza in roots. - New Phytologist 84: 489-500.

[16] Harikumar, V. S., Blaszkowski, J., Medhanie, G., Kanagaraj, M. K., Deepak Samuel, V. (2015): Arbuscular mycorrhizal fungi colonizing the plant communities in Eritrea, Northeast Africa. - Applied Ecology and Environmental Research 13(1): 193-203.

[17] IFJU (1968): Methods of Analyses. Method-8. - International Federation of Fruit Juice Producers, 10. Rue de Liege, Paris, France.

[18] Janos, D. P. (2007): Plant responsiveness to mycorrhizas differs from dependence upon mycorrhizas. - Mycorrhiza 17(2): 75-91.

[19] Jansa, J., Mozafar, A., Frossard, E. (2003): Long-distance transport of P and Zn through the hyphae of an arbuscular mycorrhizal fungus in symbiosis with maize. - Agronomy 23(5-6): 481-8.

[20] Klironomos, J. N. (2003): Variation in plant response to native and exotic arbuscular mycorrhizal fungi. - Ecology 84(9): 2292-2301.

[21] Koske, R. E., Gemma, J. N. (1989): A Modified Procedure for Staining Roots to Detect VAM. - Mycological Research 92(4): 486-505.

[22] Leifheit, E. F., Verbruggen, E., Rillig, M. C. (2014): Rotation of hyphal in-growth cores has no confounding effects on soil abiotic properties. - Soil Biology and Biochemistry 79: $78-80$. 
[23] Liu, S., Guo, X., Feng, G., Maimaitiaili, B., Fan, J., He, X. (2016): Indigenous arbuscular mycorrhizal fungi can alleviate salt stress and promote growth of cotton and maize in saline fields. - Plant Soil 398: 195-206.

[24] Olsen, S. R., Dean, L. A. (1965): Phosphorus. Chemical and microbiological properties. In: Black, C. A. (ed.) Methods of Soil Analysis, Part 2. - Am. Soc. Agron. Inc, Publisher, Madison, Wisconsin, USA, pp. 1035-1048.

[25] Ortas, I. (2012a): Do maize and pepper plants depend on mycorrhiza in terms of phosphorus and zinc uptake? - Journal of Plant Nutrition 35(11): 1639-1656.

[26] Ortas, I. (2012b): The effect of mycorrhizal fungal inoculation on plant yield, nutrient uptake and inoculation effectiveness under long term field conditions. - Field Crops Research 125: 35-48.

[27] Ortas, I. (2018): Role of mycorrhiza on mineral nutrition of fruit trees. - In: Mimmo, T., Pii, Y., Scandellarri, F. (eds.) VIII International Symposium on Mineral Nutrition of Fruit Crops, pp. 271-283.

[28] Ortas, I. (2019a): Role of Microorganisms (Mycorrhiza) in Organic Farming. - In: Chandran, S., Unni, M. R., Thomas, S. (eds.) Organic Farming: Global Perspectives and Methods, pp. 181-211.

[29] Ortas, I. (2019b): Under field conditions, mycorrhizal inoculum effectiveness depend on plant species and phosphorus nutrition. - Journal of Plant Nutrition 42(18): 2349-2362.

[30] Oztürkmen, A. R., Ramazanoğlu, E., Almaca, A., Çakmaklı, M. (2020): Effect of intercropping on soil physical and chemical properties in an olive orchard. - Applied Ecology and Environmental Research 18(6): 7783-7793.

[31] Pischl, P. H., Barber, N. A. (2017): Plant responses to arbuscular mycorrhiza under elevated temperature and drought. - Journal of Plant Ecology 10(4): 692-701.

[32] Rafique, M., Ortas, I. (2018): Nutrient uptake-modification of different plant species in Mediterranean climate by arbuscular mycorrhizal fungi. - European Journal of Horticultural Science 83(2): 65-71.

[33] Sanders, I. R., Koch, A., Kuhn, G. (2003): Arbuscular mycorrhizal fungi: Genetics of multigenomic, clonal networks and its ecological consequences. - Biological Journal of the Linnean Society 79(1): 59-60.

[34] Simpson, D., Daft, M. J. (1990): Spore production and mycorrhizal development in various tropical crop hosts indicted with Glomus clarium. - Plant and Soil 121: 171-178.

[35] Smith, S. E., Smith, F. A., Jakobsen, I. (2003): Mycorrhizal fungi can dominate phosphate supply to plants irrespective of growth responses. - Plant Physiology 133: 16-20.

[36] Smith, S. E., Read, D. J. (2008): Mycorrhizal Symbiosis. - $3^{\text {rd }}$ ed. Academic Press.

[37] Sreenivasa, M. N., Kirshnaraj, P. U., Gangadhara, G. A., Manjunatah, H. M. (1993): Response of chilli (C. annuum L.) to the inoculation an efficient vesicular-arbuscular mycorrhizal fungus. - Scienta Horticulturae 53: 45-52.

[38] Sylvia, D. M., Jarstfer, A. G. (1994): Production of inoculum and inoculation with arbuscular mycorrhizal fungi. - Management of Mycorrhizas in Agriculture, Horticulture and Forestry. Kluwer Academic Publishers. Printed in the Netherlands, pp. 231-238.

[39] Tanwar, A., Aggarwal, A., Kadian, N., Gupta, A. (2013): Arbuscular mycorrhizal inoculation and super phosphate application influence plant growth and yield of Capsicum annuum. - Journal of Soil Science and Plant Nutrition 13(1): 55-66.

[40] Wang, X., Werf, W., Yu, Y., Hoffland, E., Feng, G., Kuyper, T. (2020): Field performance of different maize varieties in growth cores at natural and reduced mycorrhizal colonization: yield gains and possible fertilizer savings in relation to phosphorus application. - Plant Soil 450(1-2): 613-624. 